\title{
ANALISIS PERAN AUDIT OPERASIONAL DALAM MENINGKATKAN EFEKTIVITAS PENGENDALIAN INTERN PENJUALAN PADA PD. ACB BANJARASARI
}

\author{
Oleh: \\ Benny Prawiranega \\ Dosen Program Studi Akuntansi Fekultas Ekonomi Universitas Galuh Ciamis \\ Jl. R.E. Martadinata No. 150, Ciamis 46274 Jawa Barat \\ Email: benny.feunigal@gmail.com
}

\begin{abstract}
ABSTRAK
Penelitian ini menganalisis pelaksanaan audit operasional, efektifitas pengendalian intern penjualan, serta menganalisis peran audit operasional dalam meningkatkan efektivitas pengendalian intern penjualan pada PD. ACB Banjarsari. Metode penelitian merupakan cara ilmiah (rasional, empiris dan sistematis) untuk mendapatkan data dengan tujuan dan kegunaan tertentu, metode yang peneliti gunakan adalah metode deskriptif. Dari hasil penelitian dan pembahasan yang telah penulis lakukan pada PD. ACB Banjarsari, maka dapat penulis simpulkan bahwa Audit Operasional pada PD. ACB Banjarsari telah dilaksanakan dengan cukup memadai serta berjalan sesuai dengan ketentuan yang berlaku. Hal ini dapat dilihat dari adanya tahapan-tahapan Audit yang meliputi perencanaan, pelaksanaan, pelaporan dan tindak lanjut telah dilaksanakan sesuai dengan ketentuan yang berlaku. Pengendalian intern Penjualan PD. ACB Banjarsari telah dilaksanakan dengan memadai dan efektif. Hal ini dapat dilihat dengan dilaksanakannya unsur-unsur pengendalian intern sesuai dengan ketentuan yang berlaku, yaitu (1) lingkungan pengendalian, (2) penaksiran resiko, (3) aktivitas pengendalian, (4) informasi dan komunikasi, (5) serta pemantauan selalu dilaksanakan dengan melibatkan seluruh bagian yang berhubungan dengan bagian penjualan. Sedangkan Pelaksanaan Audit Operasional yang memadai telah meningkatkan efektifitas pengendalian intern penjualan pada PD. ACB Banjarsari. Hal tersebut dibuktikan dengan rendahnya tingkat penyimpangan yang terjadi pada prosedur penjualan. Dengan demikian dapat dikatakan bahwa Audit Operasional yang memadai berperan dalam meningkatkan efektifitas pengendalian intern penjualan pada PD. ACB Banjarsari.
\end{abstract}

Kata Kunci: Audit Operassional, Pengendalian Intern Penjualan

\section{PENDAHULUAN}

Perkembangan dunia perekonomian saat ini dan semakin tingginya tingkat persaingan dalam dunia usaha menuntut perusahaan mempunyai keunggulan bersaing (competitive advantage) untuk terus bisa berkompetisi. Tidak sedikit perusahaan yang terhenti laju operasionalnya karena tidak mampu mempertahankan eksistensi perusahaannya. Sebagian besar kegagalan tersebut biasanya disebabkan karena perusahaan tidak konsisten dalam menjalankan operasi perusahaannya, ditambah lagi dengan kurangnya tenaga profesional di dalam perusahaan, sehingga perusahaan tidak dapat mengikuti perkembangan ekonomi yang terjadi saat ini. Hal tersebut menuntut adanya efektivitas dan efisiensi dalam menjalankan kegiatan operasional perusahaan. Keinginan untuk mendapatkan laba perusahaan yang optimal merupakan suatu niat dasar bagi manajer dalam perusahaan untuk menggerakan semua sumber daya yang ada.
Semakin maju dan berkembangnya suatu perusahaan akan diikuti dengan semakin kompleksnya aktivitas serta permasalahan yang dihadapi oleh perusahaan. Sehingga manajemen akan menghadapi kesulitan dalam mengendalikan secara langsung, ditambah dengan adanya tuntutan efisiensi, efektivitas dan ekonomis dari penggunaan berbagai sumber daya yang tersedia. Hal tersebut menuntut manajemen untuk melakukan aktivitas operasional perusahaan secara efektif dan efisien untuk mendukung tercapainya sasaran dan tujuan perusahaan yang telah ditetapkan, oleh karena itu diperlukan alat yang dapat mengukur efektivitas dan efisiensi dari bidang-bidang fungsional yang mampu menciptakan suatu peringatan dini bagi pengelolaan perusahaan yang akhirnya akan memberikan dukungan terhadap pencapaian tujuan perusahaan.

Audit operasional adalah salah satu sarana yang digunakan untuk mengevaluasi efektivitas pengelolaan suatu perusahaan. Pengertian audit operasional berdasarkan publikasi Institute of 
Internal Auditors (IIA) yang dikutip oleh Amin Widjaja Tunggal (2000: 4) adalah sebagai barikut:

"Operasional Auditing adalah suatu proses yang sistematis dari penilaian efektivitas, efisiensi dan ekonomisasi operasi suatu organisasi yang dibawah pengendalian manajemen dan melaporkan kepada orang yang tepat hasil dari penilaian beserta rekomendasi untuk perbaikan".

Melalui audit operasional, pihak manajemen perusahaan dapat mengetahui sampai sejauh mana pencapaian aktivitas operasi perusahaan, masalah-masalah yang dihadapai perusahaan dan bagaimana cara mengatasi permasalahan-permasalahan tersebut.

Audit operasional tidak terlepas dari adanya pengendalian intern perusahaan, dimana pengendalian intern dirancang untuk membantu manajer melakukan pekerjaannya dengan lebih baik (Swyer's, 2005: 51). Berikut adalah pengertian pengendalian intern menurut Commite of Sponsoring Organization (COSO, 2007):

"Internal control is a process, effected by an entity's board of directors, management, and other personnel, designed to provide reasonable assurance regarding the achievement of objectives in the following categories: (1) effectiveness and efficiency of operations; (2) reability of financial reporting; and (3) compliance with applicable laws and regulations".

Tercapainya efektivitas dan efisiensi kegiatan, merupakan salah satu tujuan utama pengendalian intern yang dikemukakan oleh COSO. Penjualan merupakan salah satu kegiatan yang sangat penting bagi perusahaan dagang, begitupun bagi PD. ACB Banjarsari, dimana kegiatan utamanya adalah melakukan aktivitas jual-beli barang dagang. Volume penjualan merupakan hal yang sangat penting untuk terus ditingkatkan, karena penjualan merupakan salah satu unsur penentu laba yang dihasilkan perusahaan.

Berdasarkan uaraian di atas penulis tertarik untuk melakukan penelitian dengan menganalisis peran audit operasional dalam mewujudkan efektivitas pengendalian intern penjualan, dimana penelitian dilakukan pada PD. ACB Banjarsari.

\section{METODE PENELITIAN \\ Metode Penelitian}

Metode penelitian merupakan cara ilmiah (rasional, empiris dan sistematis) untuk mendapatkan data dengan tujuan dan kegunaan tertentu, metode yang peneliti gunakan adalah metode deskriptif.

\section{Tahapan-tahapan Penelitian}

Dalam pelaksanaan penelitian penulis membagi kedalam enam tahapan, yaitu:

1) Pengurusan izin dan survey pendahuluan

2) Persiapan sarana dan prasarana penelitian

3) Studi Kepustakaan

4) Pengumpulan data

5) Analisis data

6) Pembuatan laporan dan seminar hasil

\section{Tempat Penelitian}

Dalam penelitian ini, penulis melakukan penelitian pada PT. ACB Banjarsari yang beralamat di JL. Raya Banjarsari No. 126 Banjarsari, Ciamis 46383.

\section{Peubah yang Diamati atau Diukur}

Adapun peubah yang diamati dalam penelitian ini adalah audit operasional dan pengendalian intern penjualan.

\section{Desain atau Model Penelitian}

Desain atau model penelitian merupakan tipe penelitian yang akan digunakan (Road Map) yang disesuaikan dengan permasalahan dalam penelitian.

Desain penelitian yang akan diguanakan peneliti adalah deskriptif dengan langkahlangkah:

1) Pengumpulan data

2) Analisis data

3) Menjelaskan lebih dalam tentang hasil penelitian

4) Mengambil kesimpulan dan menyajikan saran.

\section{Rancangan Penelitian}

Untuk lebih terarah peneliti membuat rancangan penelitian dengan menggunakan oberservasi ilmiah, yang terdiri dari:

1) Observasi tersebut dirancang untuk menjawab pertanyaan penelitian

2) Dirancang dan dilaksanakan secara sistematis

3) Merekam secara sistematis seluruh hal yang berhubungan dengan kejadian, keadaan, dan apapun yang dianggap baru (aneh) berkaitan dengan proporsi penelitian 
4) Menggunakan kendali-kendali yang tepat

5) Melakukan perhitungan, prediksi yang valid dan reliabel, serta didasari kejadian yang diamati.

\section{Teknik Pengumpulan Dan Analisis Data}

Teknik pengumpulan data yang digunakan dalam penelitian ini adalah sebagai berikut:

1) Dokumentasi

Mengumpulkan data yang diperlukan mengenai audit operasional dan pengendalian intern penjualan.

2) Observasi

Mengumpulkan data dengan cara mengamati langsung ke tempat penelitian.

3) Riset Kepustakaan

Penelitian dengan membaca buku-buku literatur, diktat serta makalah yang diperlukan sehubungan dengan masalah yang diteliti.

Dalam teknik analisis data penulis menggunakan metode deskriptif analisis, yaitu dengan cara:

1) Menganalisis secara deskriptif mengenai pelaksanaan audit operasional.

2) Menganalisis secara deskriptif mengenai pengendalian intern penjualan.

3) Menganalisis secara deskriptif peran audit operasional dalam meningkatkan efektivitas pengendalian intern penjualan.

\section{HASIL PENELITIAN DAN PEMBAHASAN}

Hasil Penelitian dan Pembahasan Mengenai Audit Operasional Pada Perusahaan Dagang ACB Banjarsari

Kendala utama yang sering dihadapi oleh seorang pemeriksa dalam menjalankan tugas Audit Operasional adalah menentukan untuk mengevaluasi apakah efisien dari bagian/unit yang diperiksa telah tercapai dalam Audit Keuangan Standar Akuntansi Keuangan dapat dipakai sebagai kriteria umum untuk menilai kewajaran penyajianya, sedangkan untuk Audit Operasional tidak ditemukan kriteria standar seperti itu.

\section{Program Audit Operasional Biaya Produksi}

\section{Ruang Lingkup}

Ruang lingkup Audit Operasional adalah bagian biaya produksi PD. ACB Banjarsari. Adapun tujuan dari Audit pada bagian penjualan ini adalah untuk mengetahui bagaimana keadaan penjualan pada periode berjalan, dan memberikan rekomendasi atau saran perbaikan kepada manajemen atas temuan kelemahan selama pemeriksaan sehingga nantinya aktivitas perusahaan khusunya aktivitas penjualan berjalan dengan efiktif.

\section{Tahap-tahap Pemeriksaan}

Pada pokoknya kerja untuk melaksanakan pemeriksaan dibagi atas dua bagian, yaitu bagian Audit pendahuluan yang merupakan tahap pengumpulan data dan informasi yang berkaitan dengan perusahaan dan pemeriksaan lanjutan untuk memperoleh bukti dan temuan sebagai dasar analisis dan pemberian saran perbaikan atau rekomendasi.

a. Audit Pendahuluan

Pada tahap ini dimaksud untuk mencari informasi yang berguna untuk mengidentifikasi kelemahan-kelemahan yang ada dan data yang diperoleh guna untuk pelaksanaan pemeriskaan lanjutan, khusus pada PD. ACB Banjarsari yang penulis teliti, Audit pemeriksan pendahuluan dilakukan dengan mengumpulkan data tertulis dan tidak tertulis mengenai hal-hal yang berkaitan dengan fungsi penjualan. Mengacu pada teori yang ada maka dalam Audit pendahuluan hal ini dibagi menjadi 2 (dua) tahap yaitu sebagai berikut:

1) Mencari Data Tertulis

Tujuan dari tahap pertama ini adalah untuk menetapkan apakah perusahaan menetapkan praktek manajemen secara konsisten. Untuk itu pada tahap pertama yang berhubungan dengan objek menurut data-data tertulis diantaranya uraian tugas, jadwal tugas, hasil penjualan, biaya penjualan, anggaran penjualan dan laporan-laporan. Hal ini yang berkaitan dengan jalannya kegiatan penjualan antara lain:

a) Memeriksa urutan berbagai jenis dokumen, seperti salinan faktur penjualan, mengamati nomor atau faktur yang hilang dan ganda atau diluar urutan normal.

b) Data kepegawaian yang meliputi jumlah karyawan, struktur organisasi, program kerja perusahaan per tahun dan lain-lain.

c) Daftar penjualan yaitu volume penjualan, perbandingan anggaran penjualan, distribusi, dan biaya usaha dengan realisasinya.

2) Wawancara Dengan Personil

Untuk mengetahui perencanaan dan pengendalian penjualan pada perusahaan 
dilakukan melalui wawancara dengan manajer produksi adalah bagian kedua dari tahap pendahuluan dari Audit Operasional penjualan. Dalam tahap ini melakukan wawancara dengan orangorang langsung dengan objek pemeriksaan diantaranya Bagian Keuangan, Bagian Penjualan, Tata Usaha dan para karyawan khususnya bagian penjualan. Data-data yang diperoleh dari wawancara ini dijadikan pelengkap datadata yang diperoleh dari tahap sebelumnya.

b. Pemeriksaan Lanjutan

Pemeriksaan lanjutan dilakukan dengan mengadakan pembahasan dan analisa atas data-data yang telah diperoleh pada tahap pendahuluan. Analisa dan pembahasan ini dipakai sebagai dasar untuk pemberian rekomendasi dan saran jika ditemukan halhal yang dipandang perlu untuk diperbaiki agar aktivitas penjualan berjalan lebih efektif.

\section{Pelaksanaan Program Audit Operasional}

Sebelum melakukan proses penjualan sebaiknya diadakan perencanaan terlebih dahulu, hal ini dimaksudkan agar jumlah yang siap dijual tepat serta sumber daya yang ada bisa dimanfaatkan seoptimal mungkin. Perencanaan diperlukan untuk menentukan tindakan apa yang harus dilakukan dan cara-cara untuk melakukan tindakan tersebut. karena sifat dan keteraturan proses penjualan yang ada maka PD. ACB Banjarsari dapat dikelompokkan ke dalam perusahaan yang melakukan aktivitas penjualan secara kontinyu, maka dengan demikian unsur terpenting dari PD. ACB Banjarsari adalah perencanaan dan pengendalian penjualan.

Berdasarkan hasil obersevasi yang didapat ternyata kegiatan perencanaan dan pengendalian penjualan ditangani oleh Store Manajer yang membawahi bagian kassa,bagian area, bagian gudang, bagian CP dan bagian EDP, kegiatan perencanaan dan pengendalian penjualan yang dilaksanakan pada PD. ACB Banjarsari yaitu:

\section{Perencanaan}

Aspek perencanaan ditekenkan pada kemampuan untuk menyusun perencanaan jangka menengah yang mencerminkan visi dan misi perusahaan sekaligus menentukan arah pengembangan perusahaan di masa mendatang serta menyusun struktur organisasi yang mencermintakn juga wewenang dan tanggung jawab yang seimbang serta interaksi saling terpengaruh antar bagian dengan efisien.

\section{Pengendalian}

Pengendalian meliputi standar operasi dan kerja pedoman-pedoman penilaian yang berfungsi sebagai acuan dalam pelaksanaan kegiatan serta tolak ukur bagi pimpinan untuk menilai kegiatan dan hasil kegiatan, selain itu digunakan untuk menilai tingkat ketaatan managemen dalam melaksanakan kegiatan perusahaan. Apakah perangkat pengendalian yang telah disusun atau ditetapkan sebagai kebijaksanaan perusahaan telah diimplementasikan, atau jika dianggap kurang sesuai sejauh mana upaya untuk melakukan penyesuaian dengan perubahan yang terjadi.

\section{Laporan Audit Operasional dan Tindak Lanjut}

Langkah akhir dari suatu Audit adalah dibuatnya laporan hasil pemeriksaan. Berikut ini laporan hasil audit bagian penjualan pada PD. ACB Banjarsari.

1. Tujuan dan Ruang Lingkup Pemeriksaan

Tujuan dari Audit ini adalah untuk mengetahui apakah prosedur penjualan sudah dapat beroperasi dengan efektif dan efisien. Audit ini berguna untuk mengetahui, mengidentifikasi dan merekomendasikan kemungkinan pengembangan dan perbaikan.

Ruang lingkup audit operasional atas bagian penjualan meliputi analisis tujuan dan organisasi bagian penjualan, analisis sistem dan prosedur penjualan, analisis perencanaan dan pengendalian penjualani.

2. Temuan

Dari kebiasaan yang berlangsung di PD. ACB Banjarsari diketahui bahwa pelaksanaan penjualan dan biaya-biaya pada suatu tahun tertentu akan dibandingkan dengan realisasi tahun yang bersangkutan dari perbandinganperbandingan ini akan diketahui kemungkinan terjadinya penyimpangan-penyimpangan dalam pelaksanaan prosedur penjualan seperti :

a. Adanya ketidaksesuaian pencatatan penjualan.

b. Transaksi penjualan yang ada belum dicatat.

c. Penjualan tidak dicatat secara tepat waktu.

d. Penjualan yang dicatat adalah bukan untuk jumlah barang yang akan dijual dan ditagih dan dicatat dengan tidak benar/ tidak akurat..

e. Transaksi penjualan tidak diklasifikasikan dengan semestinya 
f. Transaksi penjualan tidak dimasukan kedalam berkas induk piutang usaha dan tidak diikhtisarkan dengan benar.

\section{Rekomendasi}

Berdasarkan penemuan yang diperoleh selama pemeriksaan, akhirnya dapat diusulkan beberapa rekomendasi (saran) sebagai berikut :

a. Untuk menjaga adanya ketidaksesuaian pencatatan penjualan, maka penjualan yang dicatat adalah untuk pengiriman ke pelanggan non fiktif.

b. Transaksi penjualan harus diotorisasi dengan semestinya.

c. Harus ada laporan penjualan yang dipertanggungjawabkan.

d. Perlua dibuat salinan faktur penjualan.

Rekomendasi dari hasil audit operasinal ini merupakan sarana yang harus dilakukan oleh manajemen yang merupakan hasil temuan pemeriksaan berupa penyimpangan dan kondisi tidak lazim dari ketentuan-ketentuan yang berlaku yang menyangkut operasi/keuangan. Rekomendasi yang dikeluarkan dari hasil pemeriksaaan operasional terhadap manajemen atau objek yang diperiksa seyogyanya ditindaklanjuti dengan melakukan langkahlangkah yang konkrit sebagai upaya perbaikan yang dilakukan agar kemungkinan kesalahan atau kelemahan di masa mendatang tidak lagi dijumpai.

Dengan demikian audit operasional yang dilaksanakan pada PD. ACB Banjarsari sudah memadai, hal ini terbukti dalam pelaksanaan audit operasional sudah mencakup unsur audit operasional yang terdiri dari perencanaan, pelaksanaan, pelaporan dan tindak lanjut.

\section{Hasil Penelitian dan Pembahasan Mengenai Pengendalian Intern Penjualan Pada Perusahaan Dagang ACB Banjarsari}

Pengendalian intern penjualan merupakan suatu upaya agar tujuan perusahaan baik yang bersifat administratif maupun akuntansi dapat tercapai. Pengendalian intern yang baik mencakup lima hal yaitu (1) Lingkungan Pengendalian, (2) Penaksiran Risiko, (3) Aktivitas Pengendalian, (4) Informasi dan Komunikasi, dan (5) Pemantauan.

Pada Perusahaan Dagang ACB Banjarsari telah menerapkan pengendalian intern penjualan yang dibuktikan dengan telah dilaksanakannya unsur-unsur yang mendukung terhadap pengendalian intern penjualan, tetapi belum sepenuhnya terlaksana sesuai dengan prinsip akuntansi yang berlaku umum. Adapun unsurunsur pengendalian intern tersebut adalah:

\section{Lingkungan Pengendalian}

Lingkungan pengendalian merupakan sarana dan prasarana yang ada di dalam organisasi atau perusahaan untuk menjalankan sistem pengendalian intern yang baik. Perusahaan Dagang ACB Banjarsari adalah salah satu bentuk usahai yang bergerak dalam bidang ritel atau swalayan, walaupun demikian pihak manajemen memandang perlu adanya pengendalian. Hal ini dapat terlihat dari adanya ketentuan-ketentuan yang berhubungan dengan lingkungan pengendalian.

Adapun yang menjadi faktor dalam menciptakan lingkungan pengendalian pada Perusahaan Dagang ACB Banjarsari neng adalah sebagai berikut:

1. Komitmen Manajemen terhadap Integritas dan Nilai-nilai Etika

Peraturan dan nilai-nilai etika bekerja di Perusahaan Dagang ACB Banjarsari ditentukan dan diberitahukan kepada karyawan sejak karyawan masuk menjadi bagian dari perusahaan tersebut. Uraian kerja ini berisi apa yang harus dikerjakan oleh karyawan dan kode etik yang harus ditaati oleh setiap karyawan. Peraturan tersebut harus ditaati dan dijalankan oleh setiap karyawan pada Perusahaan Dagang ACB Banjarsari.

2. Filosofi yang Dianut oleh Manajemen dan Gaya Operasional yang Dipakai oleh Manajemen

Manajemen melalui aktivitasnya menyediakan isyarat yang jelas kepada karyawan tentang pentingnya pengendalian intern persediaan, manajemen telah memberikan contoh yang baik pada karyawan. Hal ini dapat dilihat dari selalu adanya pengontrolan, penyelesaian masalah dilakukan dengan cepat tanggap dan selalu memprioritaskan aturan agar terlaksana sesuai dengan apa yang telah ditetapkan perusahaan. Perusahaan menerapkan aturan yang baik dan sehat dimana karyawan selalu dilibatkan sesuai dengan tugas dan tanggung jawab yang telah ditentukan dalam setiap kegiatan di perusahaan. Jika terdapat penyimpangan dari karyawan mengenai aturan yang berlaku dalam pengendalian intern, maka terdapat sanksi bagi karyawan tersebut. Misalnya dengan diberikan teguran terlebih dahulu atau peringatan dan jika tetap melakukan kesalahan serta tidak mentaati aturan, maka 
perusahaan melakukan pemutusan hubungan kerja atau pemecatan tanpa hormat.

3. Struktur Organisasi

Di Perusahaan Dagang ACB Banjarsari telah terdapat struktur organisasi yang memisahkan fungsi dari masing-masing bagian dalam perusahaan, sehingga tugas yang diemban oleh tiap-tiap bagian dapat terlaksana dengan baik. Pembentukan struktur organisasi berdasarkan kebutuhan operasional dengan memperhatikan adanya pemisahan tugas, pembagian tugas dan wewenang yang jelas dari masing-masing fungsi sehingga dalam perkembangannya diharapkan dapat terkendali untuk mencapai tujuan perusahaan.

4. Komite Audit untuk Dewan Direksi

Untuk komite audit belum dilaksanakan di Perusahaan Dagang ACB Banjarsari, karena perusahaan tersebut tidak mengetahui seperti apa kinerja dari komite audit tersebut.

5. Metode Pembagian Tugas dan
Tanggungjawab

Struktur organisasi pada Perusahaan Dagang ACB Banjarsari memperlihatkan adanya pemisahan tugas disertai dengan pemberian wewenang dan tanggung jawab yang jelas, sehingga setiap pegawai dalam perusahaan mengerti dan mengetahui apa yang menjadi pekerjaannya, wewenang apa yang dimilikinya, bagaimana dan kepada siapa laporan disampaikan.

6. Kebijakan dan Taktik yang Menyangkut Sumber Daya Manusia

Kebijakan mengenai Sumber Daya Manusia (SDM) atau tenaga kerja dapat dilihat dalam perekrutan karyawan. Pada Perusahaan Dagang ACB Banjarsari, perekrutan karyawan tidak seperti pada perusahaan-perusahaan lainnya yaitu dengan cara penyeleksian calon karyawan, tetapi pada Perusahaan Dagang ACB Banjarsari karyawan didapat dari masyarakat di sekitar perusahaan, karena perusahaan tersebut lebih menekankan karyawan dari masyarakat sekitar terlebih dahulu dan kalau sudah tidak ada baru merekrut dari daerah lain. Selain itu, tidak ada aturan pengalaman kerja ataupun aturanaturan lainnya, namun perusahaan tersebut merekrut karyawan yang membutuhkan pekerjaan tersebut.

\section{Penilaian Risiko}

Penilaian risiko merupakan kegiatan yang dilakukan oleh manajemen dalam mengidentifikasi dan menganalisis risiko yang menghambat perusahaan dalam mencapai tujuannya. Risiko dapat berasal dari dalam maupun luar perusahaan.

Penilaian risiko harus diperhitungkan agar dapat mengendalikan risiko-risiko yang mungkin terjadi sehingga tujuan pengendalian intern tercapai. Dari hasil pengamatan, dalam menghadapi risiko seperti bencana dan pelanggaran karyawan di Perusahaan Dagang ACB Banjarsari telah diprediksi sebelumnya dan diantisipasi untuk menjaga kestabilan usaha. Risiko-risiko yang terjadi dalam perusahaan harus diminimalisir agar perusahaan tetap berjalan sebagaimana mestinya.

Jika terjadi pelanggaran yang dilakukan oleh karyawan misalnya dalam hal kepatuhan terhadap kode etik kerja dan penyalahgunaan wewenang, tindakan yang diambil pihak perusahaan adalah memberikan peringatan bahkan apabila terjadi pelanggaran yang tergolong berat maka akan dilakukan pemecatan. Pelanggaran yang mungkin terjadi pada perusahaan Dagang ACB Banjarsari adalah pemengambil barang dagangan yang bukan hak nya seperti mengambil barang yang siap untuk dijual. Pemilik akan langsung melakukan pemecatan tanpa adanya peringatan terlebih dahulu apabila karyawan melakukan pelanggaran tersebut.

Dari hasil penelitian dan pembahasan diatas, penulis dapat mengambil kesimpulan bahwa penilaian risiko telah cukup diperhatikan oleh pihak Perusahaan Dagang ACB Banjarsari. Hal ini bisa dilihat dari penilaian risiko seperti bencana dan pelanggaran karyawan di Perusahaan Dagang ACB Banjarsari telah diprediksi sebelumnya dan diantisipasi untuk menjaga kestabilan usaha. Sehingga penilaian risiko tersebut cukup mendukung terhadap diterapkannya pengendalian intern penjualan.

\section{Aktivitas Pengendalian}

Aktivitas pengendalian adalah suatu unsur pengendalian intern selain dari empat komponen lainnya, yang dibuat manajemen untuk mencapai tujuan perusahaan. Aktivitas pengendalian dapat memberikan jaminan bahwa aktivitas yang dilakukan dapat menghindari risiko perusahaan. Dari hasil penelitian aktivitas pengendalian yang dilakukan oleh Perusahaan Dagang ACB Banjarsari adalah sebagai berikut:

1. Pemberian Otorisasi atas Transaksi dan Kegiatan

Sistem otorisasi transaksi yang terjadi di Perusahaan Dagang ACB Banjarsari mencakup transaksi pembelian, penjualan, penerimaan kas 
dan pengeluaran kas. Manajemen dalam perusahaan tersebut memberikan wewenang kepada karyawan bagian penjualan untuk menjual barang tertentu dengan harga tertentu pula. Kapanpun pelanggan memerlukan barang tersebut maka karyawan tadi diijinkan untuk memulai, mencatat dan memproses transaksi penjualan. Transaksi pembelian dilakukan oleh karyawan bagian pembelian dimana karyawan tersebut diberi wewenang untuk membeli persediaan barang dagangan dan kemudian disimpan di gudang sebagai persediaan perusahaan untuk dijual.Untuk transaksi pembelian dan penjualan, pengotorisasian dilakukan oleh Pimpinan perusahaan (pemilik). Sedangkan untuk penerimaan dan pengeluaran kas diotorisasi oleh Bendahara.

2. Pembagian Tugas dan Tanggung jawab

Struktur organisasi di Perusahaan Dagang

ACB Banjarsari dirancang sedemikian rupa untuk mempertegas tugas dan tanggung jawab masing-masing bagian dan memastikan tidak adanya pelimpahan wewenang yang berpotensi menimbulkan kecurangan. Dalam kegiatan pengadaan dan pengelolaan persediaan di Perusahaan Dagang ACB Banjarsari sudah dilakukan pembagian tugas dan tanggung jawab yang cukup antara petugas yang menerima kiriman barang, yang melakukan pengecekan dan pencatatan, sehingga tidak ada bagian yang melakukan tugas rangkap. Hal ini menghindarkan dari kemungkinan kecurangankecurangan yang akan merugikan perusahaan.

3. Perancangan dan Penggunaan Dokumen dan Catatan yang Baik

Dokumen melaksanakan fungsi mengirimkan informasi antar organisasi dan klien dan diantara organisasi yang berbeda. Dokumen harus memadai untuk menjamin yang wajar bahwa semua asset dikendalikan dengan baik dan semua transaksi dicatat dengan tepat. Pada Perusahaan Dagang ACB Banjarsari pencatatan selalu didasarkan pada dokumen yang ada dan dokumen yang digunakan telah memenuhi prinsip relevan suatu dokumen atau arsip. Hal ini terlihat dari:

a. Bernomor urut cetak,

b. Disiapkan pada waktu transaksi berlangsung atau segera sesudah itu,

c. Cukup sederhana untuk dipahami,

d. Dirancang untuk berbagai penggunaan agar memperkecil jumlah formulir yang berbeda.

4. Perlindungan yang Cukup terhadap Kekayaan dan Catatan Perusahaan
Perlindungan yang cukup terhadap kekayaan dan catatan pada Perusahaan Dagang ACB Banjarsari adalah dengan adanya pengawasan dan penyeliaan (supervision) yang efektif dan pembagian tugas dan tanggungjawab yang baik, penyelenggaran catatan aktiva dan penyajian informasi yang akurat, sehingga dapat menggambarkan keadaan yang sebenarnya, atau setidak-tidaknya mendekati yang sesungguhnya, pembatasan akses fisik terhadap akses dan berbagai dokumen penting, penyediaan tempat penyimpanan yang baik, dan pembatasan akses ruang-ruang penting, yaitu ruang tempat menyimpan dokumen penting yaitu ruang tempat menyimpan dokumen penting.

5. Pemeriksaan Independen terhadap Kinerja Perusahaan

Peninjauan kinerja di Perusahaan Dagang ACB Banjarsari yang berhubungan dengan persediaan dilaksanakan setiap hari setelah jam kerja berakhir, selain itu juga peninjauan dilakukan ketika ada kiriman barang dengan dilakukannya serangkaian kegiatan yang membentuk prosedur penerimaan barang.

Peninjauan kembali kinerja dalam hubungannya dengan pengendalian intern penjualan adalah dimaksudkan untuk mengawasi semua kegiatan pengelolaan penjualan pada Perusahaan Dagang ACB Banjarsari.

\section{Informasi dan Komunikasi}

Berdasarkan hasil penelitian di Perusahaan Dagang ACB Banjarsari khususnya untuk kegiatan pengelolaan penjualan telah dilaksanakan dengan baik, sesuai dengan ketentuan yang telah ditetapkan. Adapun prosedur-prosedur pengelolaan penjualan menggunakan dokumen-dokumen dan formulirformulir yang dapat memudahkan dalam pelaksanaan pengelolaan penjualan, sehingga dapat dilaksanakan sesuai dengan ketentuan yang telah ditetapkan. Selain itu unsur informasi dan komunikasi di Perusahaan Dagang ACB Banjarsari juga dapat dilihat dari adanya sistem informasi dan komunikasi akuntansi, yang diciptakan untuk mengidentifikasi, mengklasifikasikan, menganalisa, mencatat dan melaporkan transaksi satu satuan usaha.

Dalam menciptakan sistem informasi dan komunikasi yang efektif dan baik, dimulai dengan melakukan pemisahan fungsi dan wewenang dalam perusahaan. Salah satu bentuk informasi di Perusahaan Dagang ACB Banjarsari adalah adanya laporan mengenai 
kegiatan pengelolaan penjualan yang akan dilaporkan kepada pemilik perusahaan.

Perusahaan Dagang ACB Banjarsari telah menerapkan sistem informasi akuntansi yang terkomputerisasi meskipun masih ada yang masih secara manual sehingga dalam pelaksanaan maupun pelaporan keuangan tidak terlalu kesulitan untuk menghasilkan informasi yang akurat dan relevan juga tepat waktu.

Dari uraian diatas dapat disimpulkan bahwa informasi dan komunikasi yang dihasilkan oleh Perusahaan Dagang ACB Banjarsari sudah sesuai dengan ketentuan yang berlaku umum dan cukup memadai dengan yang diperlukan oleh pihak-pihak yang berkepentingan. Hal ini bisa dilihat dari cara penerapan sistem informasi akuntansi manual dan terkomputerisasi, sehingga cukup untuk dapat menghasilkan laporan keuangan yang relevan, akurat dan tepat waktu.

\section{Pemantauan}

Pemantauan adalah kegiatan untuk mengetahui jalannya sistem informasi akuntansi, sehingga apabila ada sesuatu berjalan tidak seperti yang diharapkan, dapat diambil tindakan segera. Sedikit saja penyimpangan dibiarkan, akan menjadi besar, dan penyimpangan besar akan menyebabkan sistem terganggu atau tidak berfungsi. Dari hasil penelitian pada Perusahaan Dagang ACB Banjarsari , pemantauan dilakukan dengan cara evaluasi rutin terhadap keadaan persediaan barang dagangan yang siap dijuan atau yang ada di gudang. Dengan adanya pemantauan, pihak pimpinan perusahaan dapat mengetahui pengelolaan penjualan barang dagangan yang berotasi selama periode tertentu.

Dari uraian diatas dapat disimpulkan bahwa pemantauan dilakukan untuk menilai dan mengawasi proses kegiatan pengelolaan penjualanan, dan dalam pelaksanaannya pemantauan telah dilaksanakan cukup memadai yang dilakukan oleh satuan pengawas intern.

Dari hasil penelitian diatas, penulis dapat menarik kesimpulan bahwa pengendalian intern penjualan yang diterapkan oleh pihak Perusahaan Dagang ACB Banjarsari sudah cukup memadai. Hal tersebut dapat dilihat dariditerapkannya unsur-unsur pengendalian intern yang meliputi lingkungan pengendalian, penilaian risiko, aktivitas pengendalian, informasi dan komunikasi serta pemantauan yang dilaksanakan dengan standar teori yang berlaku.
Dari hasil penelitian, pengendalian intern persediaan yang diterapkan oleh Perusahaan Dagang ACB Banjarsari sudah sesuai dengan aturan yang berlaku. Hal ini terbukti karena telah memenuhi unsur-unsur pengendalian intern yang umum yakni terdapatnya lingkungan pengendalian yang ditunjukkan dengan sikap manajemen yang menganggap penting pengendalian dan terdapatnya struktur organisasi, gaya operasional perusahaan yang diterapkan jika terjadi penyimpangan mengenai aturan yang berlaku diberikan sanksi bagi karyawan tersebut, dan metode pembagian tugas dan tanggungjawab yang sudah cukup jelas dan perusahaan sudah memisahkan antara fungsi pencatatan, penyimpanan dan pemberi otorisasi.

Selain itu, aktivitas pengendalian, informasi dan komunikasi sudah berjalan dengan baik. Hal ini terbukti dari sudah terlaksananya pembagian tugas dan tanggungjawab, informasi yang disampaikan kepada karyawan pun sudah cukup baik karena informasi tersebut selalu sampai dari atasan ke bawahan atau karyawan. Meskipun demikian masih terdapat kekurangan yaitu pada unsur lingkungan pengendalian dan pemantauan.

Dalam lingkungan pengendalian unsur yang belum terlaksana dengan baik adalah komite audit. Komite audit ini cukup penting bagi sebuah perusahaan karena tidak hanya karyawan yang harus diawasi, tetapi jajaran tertinggi di perusahaan pun harus diawasi oleh pihak yang berwenang. Seperti yang dikemukakan oleh Winarno (2006: 11.7-11.8) bahwa "Tidak hanya karyawan yang harus selalu diawasi, tetapi jajaran tertinggi di perusahaan pun harus diawasi dan diaudit oleh suatu komisi yang khusus dibentuk untuk itu, yaitu Komite Audit".

Selain itu, yang belum terlaksana pada Perusahaan Dagang ACB Banjarsari adalah kebijakan dalam taktik yang menyangkut Sumber Daya Manusia. Pada perusahaan belum menggunakan prosedur yang seharusnya dilakukan dalam merekrut karyawan. Hal ini dapat berisiko dalam persediaan yang ada dalam perusahan. Pimpinan tidak mengetahui seberapa menguasainya karyawan tersebut dalam bidang yang diajukan sebagai pekerjaannya.

Pihak manajemen masih belum memandang terlalu penting terhadap penilaian risiko terutama ancaman persaingan pada masa yang akan datang. Jika tidak diatasi dengan cepat, maka perusahaan dapat mengalami kerugian atas kekayaan perusahaan. Selain itu, 
pemantauan yang dilakukan Perusahaan Dagang ACB Banjarsari yng masih belum sempurna, hal ini dapat dilihat dari masih adanya kesalahan penyimpanan atau pengklasifikasian barang dan stock barang dan stock persediaan rusak yang ada di gudang ataupun barang jadi yang siap untuk dijual.

\section{Hasil Penelitian dan Pembahasan Mengenai Peran Audit Operasional Dalam Meningkatkan Pengendalian Intern Penjualan Pada PD. ACB Banjarsari}

Dalam pelaksanaan program audit operasional untuk meningkatkan efetivitas penjualan pada PD. ACB Banjarsari melalui tahapan pengumpulan data dan informasi mengenai gambaran umum perusahaan terutama pada aktivitas penjualan serta tahap audit lanjutan untuk menganalisis data-data yang diperoleh, dalam hal ini pelaksanaan audit operasinal pada PD. ACB Banjarsari sudah cukup memadai, karena penyimpanganpenyimpangan atau kecurangan-kecurangan yang dapat merugikan perusahaan atau memperhambat efektivitas penjualan yang sudah direncanakan dapat diperbaiki, audit operasional dalam pembahasan hasil penelitian hal ini sejalan dengan di komparasikan dengan teori.

Dalam tahap pelaporan dan tindak lanjut hasil temuan dan rekomendasi untuk perbaikan kelamahan-kelemahan atau penyimpanganpenyimpangan dalam penjualan dikomunikasikan dengan pihak manajemen, sehingga manajemen dapat mengetahui kelemahan-kelemahan atau penyimpanganpenyimpangan yang menyebabkan ketidakefektipan penjualan. Dalam hal ini mengarah pada tindakan manajemen untuk segera mengadakan tindakan perbaikan/penyempurnaan terhadap ketidak efektipan tersebut.

Jadi dengan adanya pelaksanaan audit operasional pada PD. ACB Banjarsari penyimpangan-penyimpangan yang terjadi yang menyebabkan ketidak efektipan dapat diperbaiki dan kelemahan/kesalahan di masa mendatang tidak lagi dijumpai sehingga efektivitas penjualan akan meningkat.

Peranan audit operasional dalam menunjang system pengendalian intern adalah audit operasional dapat mengetahui efektivitas dan efisiensi akan suatu system pengendalian intern pada suatu fungsi (misal fungsi penjualan) dari suatu perusahaan. Seperti telah dijelaskan diatas, tujuan audit operasional itu sendiri adalah memberikan penilaian terhadap efisiensi dan efektivitas serta keekonomisan dari suatu bagian operasional perusahaan yang merupakan akibat yang diharapkan dari system pengendalian intern yang baik. Hubungan ini juga dapat dilihat dari pernyataan Abdul Halim (2003:198) mengenai beberapa konsep dasar dari Sistem Pengendalian Intern, yaitu: "Sistem Pengendalian Intern diharapkan dapat mencapai tujuan audit, baik audit keuangan, audit operasional maupun audit kepatuhan serta Sistem Pengendalian Intern tidak dimaksudkan untuk memberikan jaminan yang mutlak dimana setiap Sistem Pengendalian Intern pasti mempunyai kelemahan".

\section{PENUTUP \\ Simpulan}

Dari hasil penelitian dan pembahasan yang telah penulis lakukan pada PD. ACB Banjarsari, maka dapat penulis simpulkan: (1) Bahwa Audit Operasional pada PD. ACB Banjarsari telah dilaksanakan dengan cukup memadai serta berjalan sesuai dengan ketentuan yang berlaku. Hal ini dapat dilihat dari adanya tahapan-tahapan Audit yang meliputi perencanaan, pelaksanaan, pelaporan dan tindak lanjut telah dilaksanakan sesuai dengan ketentuan yang berlaku; (2) Bahwa Pengendalian intern Penjualan PD. ACB Banjarsari telah dilaksanakan dengan memadai dan efektif. Hal ini dapat dilihat dengan dilaksanakannya unsur-unsur pengendalian intern sesuai dengan ketentuan yang berlaku, yaitu (1) lingkungan pengendalian, (2) penaksiran resiko, (3) aktivitas pengendalian, (4) informasi dan komunikasi, (5) serta pemantauan selalu dilaksanakan dengan melibatkan seluruh bagian yang berhubungan dengan bagian penjualan; (3) Pelaksanaan Audit Operasional yang memadai telah meningkatkan efektifitas pengendalian intern penjualan pada PD. ACB Banjarsari. Hal tersebut dibuktikan dengan rendahnya tingkat penyimpangan yang terjadi pada prosedur penjualan. Dengan demikian dapat dikatakan bahwa Audit Operasional yang memadai berperan dalam meningkatkan efektifitas pengendalian intern penjualan pada PD. ACB Banjarsari.

\section{Saran}

Adapun saran yang penulis dapat sampaikan berdasarkan hasil penelitian dan pembahasan yang dilakukan pada PD. ACB Banjarsari adalah sebagai berikut: (1) Bagi Perusahaan hendaknya pihak PD. ACB 
Banjarsari secara intensif selalu meningkatkan intensitas Audit Operasinal terhadap prosedur penjualan yang dilaksanakan untuk dapat lebih meminimalisir terjadinya penyimpanganpenyimpangan yang terjadi dalam aktivitas penjualan perusahaan melalui program audit yang berkesinambungan; (2) Bagi peneliti selanjutnya diharapkan ada penelitian lebih lanjut mengenai peranan variabel lainnya diluar Audit operasional yang dapat meningkatkan efektivitas pengendalian intern penjualan.

\section{DAFTAR PUSTAKA}

Amin Widjaja Tunggal. 2000. Manajemen Audit Suatu Pengantar. Jakarta: Rineka. Cipta.

Committee of Sponsoring Organizations of the Treadway Commission (COSO). 2007. Internal Control-Integrated Framework.

Halim, Abdul. 2003. Analisis Investasi. Edisi Pertama, Jakarta: Penerbit Salemba Empat

Sawyer, Dittenhofer, S. Cheiner, 2005. Internal Auditing, Buku Satu, Edisi. Kelima, Jakarta : Salemba Empat

Winarno, Wing Wahyu, 2006, Sistem Informasi Akuntansi, Yogyakarta: UPP STIM. YKPN Yogyakarta. 